\title{
REP'TILES
}

Prior to 1941 Mr. G. R. Leonard, M.B.E., made a study of snakes in the National Park, and when circumstances permit it is hoped to record his observations in a permanent form. Observations at present are confined to chance encounters.

The only item of interest recorded during 1950 was the appearance of a specimen of the "Flying" Gecko, Ptychozoon kuhli at Kuala Tahan on 29th October. Another specimen appeared on 8 th November.

\section{WILD LIFE IN ARABIA}

\section{By Desmond Foster-Vesey-Fitzgerald}

Open plains, scorching and shadeless during the summer, windswept and freezing during the winter night, present a hard environment indeed. The surprising fact is that any form of wild life has been able to exist in such utterly waterless places. Yet up to the beginning of the present century an interesting assemblage of animals existed in the Arabian desert. Even when modern rifles came into general use the species held their own in the vast spaces to a very satisfactory extent. But the last decade has witnessed the advent of a shocking predator, namely the " Mighty Jeep". It cannot be long now before motorized hunting parties will sweep Arabia's fauna into uttermost corners, where a subsequent drought will whiten its bones.

It may be of interest therefore to record the status of the more interesting animals during recent years.

The Arabian Oryx is now extinct in the northern sands of the Great Nafud. As a memorial some interesting pictures of this species have been scratched by idle shepherds on sandstone outcrops in the vicinity of Hail. In the southern sands of the Rub Al Khali the Oryx still exists.

Three species of gazelle are still widespread and reasonably numerous. The northernmost species is Loder's Gazelle, the "Rhim" of the Arab (Gazella leptoceros marica) which inhabits the gravel plains, limestone plateaux and sands of Central Arabia. This is a gazelle of the steppe where perennial dwarf shrubs are supplemented by abundant annual herbage following winter rains. It is a stocky, whitish animal which congregates in large flocks composed of fifty to a hundred individuals. It has not been observed to leap or bound like the other species but travels nevertheless at a deceptively fast speed, 
with neck outstretched, individuals composing the flock packing closely together like a flock of goats. The young are dropped during March and April and a high proportion of twins are born. The "Rhim" is the only species found on the northern gravel plains and along the fringes of the central Arabian sands, being especially abundant on the Bisaita plain and Teisiya plateau. It extends southwards into the tropic, where it has been observed congregating with the other species.

The other two species, the Dorcas Gazelle (Gazella dorcas saudiya) and the Arabian Gazelle (Gazella gazella arabica) are not always easy to distinguish at a distance, both being graceful reddish animals which leap and bound in a manner quite unlike the "Rhim".

"The Dorcas Gazelle or "Afri" appears to be confined to those parts of the interior of the peninsula where Acacia grows. It ranges widely over the great gravel plains which lie to the east of the Hejaz mountains but is only encountered in very small parties or alone.

The Arabian Gazelle or "Idmi" is also a Gazelle of Acacia country and appears to be the common specics of the coastal plains all round the peninsula where this tree occurs. But it also occurs on the highland plains of the interior with the Dorcas Gazelle and is in fact the commonest species in all the country to the east of Taif. The Arabian Gazelle is not gregarious but where it is still abundant, as for example on the plains of Dhofar where gazelle are rigidly protected by the Sultan of Oman, quite large concentrations may sometimes be seen.

Unfortunately gazelle are pathetically easy to run down with cars and if a speed of thirty miles per hour can be maintained the animals collapse after a very short time. Where broken country exists they may get away, but not always before they have been peppered with shot. Gazelle in Arabia never drink and they are able to exist without green herbage or dew. It must be presumed that the necessary moisture for their wellare is obtained from buds of peremnial plants which although encased within dry scalcs during drought periods, remain viable and ready to burst as soon as rains fall. Probably the most important plant in this category for the "Rhim" is the dwarf shrub Rhanterium eppaposum, and for the other species the various kinds of Acacia.

The Ibex exists in Arabia where a suitable habitat occurs. Such places include the sandstone gorges around Medain Saleh in the Hejaz, the basalt ranges of the Jebel Shammar around IIail, and the dricr mountains of Dhofar in Southern. 
Arabia. Only in Dhofar is it at all frequent; elsewhere its numbers have been greatly reduced. The lbex needs to drink and surface water is always available in its habitat. However, pools become few and far between during the dry season and the animal is therefore fairly easily ambushed by a patient hunter.

A Tahr (Hemitragus jayakari) was described by OldfieldThomas in 1894 from skins purchased in Muscat market. From that date nothing was heard of the animal until $W$. Thesiger collected specimens on Jebel Hafit in Oman during 1948. He reports that the animal is quite common in the inaccessible parts of the mountain and is in no danger of being shot out.

The Arabs do not discriminate between the Ibex and Tahr but use the names Bedan or Wail for both. The Ibex apparently does not occur in Oman but, as an Ibex-like animal is spoken of throughout the ranges, it appears that the Tahr is widespread and well established in that part of Arabia.

The Wolf (Canis lupus arabs) is still fairly common in Central Arabia, especially in the limestone country where springs are frequent and caverns provide suitable dens. The flockmasters destroy it whenever possible, with justification, but the species is in no immediate danger of extermination.

The Striped Hyena is widespread but nowhere common, although tracks are often seen on the Red Sea coastal plains where it is able to pick up a living along the high water mark. Elsewhere its life must be extremely hard.

The Leopard must be rare, but certainly it still exists in the Red Sea hills south of Jedda where baboons are plentiful and also in the more generously wooded hills of Dhofar. It is killed whenever possible by shepherds. Although Arabs refer to the existence of Leopards, "Nimr," in other parts of Arabia it is more than probable that they mean a kind of lynx. However, this animal's existence, and equally the Leopard's absence, in such Central Arabian districts as the Jebel Shammar cannot be confirmed.

In Arabia the Ostrich is extinct. By all accounts these birds existed in some numbers over the open gravel plains of the Bisaita in North-Western Saudi Arabia until about twenty years ago. Then, during the 1930's there was a big massacre in order to obtain plumes, but a few survivors lingered on until about 1944, when the last were killed. Ostriches are abundantly represented in the rock drawings of the Hail district, but they now no longer exist in the sands of the Great Nafud. In SouthEastern Arabia the Ostrich became extinct about sixty years ago but fragments of egg-shell can still be quite frequently 
found in the Bainuna country between the base of the Qatar peninsula and the Trucial coast.

The foregoing account shows that none of the Arabian fauna, with the exception of the Ostrich, has yet become extinct, though all are now menaced by the rapid expansion of motorized hunting parties. But it is feared that the next decade may see the end of its valiant struggle to survive in the deserts of the peninsula.

\section{NATURE RESERVES OF NATAL AND ZULULAND}

(With acknowledgments to the Report of the Natal Parks, Game and Fish P'reservation Board, April, 1950-March, 1951.)

Throughout the report the Rhinoceros (Ceratotherium simum) is referred to as the Square-lipped Rhinoceros and not as the White Rhinoceros. Both terms have been in common use for many years; the former is the more descriptive and it is hoped that the latter, which is a complete misnomer, may fall into disuse.

\section{The Natal Reserves}

Of the Natal Reserves the Royal Natal National Park, with which Rugged Glen is combined, is famed chicfly for its scenery and its attraction to the geologist and the botanist, while the purpose of the Krantzkloof is to preserve a unique area of natural vegetation. It is only in the Giant's Castle Reserve that the larger wild animals exist in great numbers. Notes on some of them follow.

Eland (more than 1,500).- The position is satisfactory, although the eland's wandering propensity causes continuous anxiety. Being exposed to illegal hunting when out of the Reserve, particularly in the south, some attempts have been made to drive the wanderers back and other similar projects are contemplated in the near future. Aerial reconnaissance proved cheaper and more reliable than ground parties to locate stray animals, and elicited the information that journeys to age-old natural mineral licks may be one reason for the wanderings of small troops of eland.

Studies of the diet of eland are being made with a view to augmenting, perhaps by planting, those foods which they favour. 